\title{
PENGARUH KINERJA KEUANGAN TERHADAP HARGA SAHAM 10 BANK TERKEMUKA DI INDONESIA
}

\author{
Indra Satria dan Iha Haryani Hatta \\ Fakultas Ekonomi \& Bisnis Universitas Pancasila \\ Email: indra_satria_feup_yahoo.co.id dan iha.haryani@yahoo.com
}

\begin{abstract}
This research is to determine the impact of financial ratios on the stock price of ten leading banks in Indonesia. This research using a purposive sampling method for the ten banks that listed on the Indonesian Stock Exchange in the years 2013-2014 with the following criteria : (1) has assets with the largest number in the years 2013-2014 (2) has information about financial ratios in the years 2013-2014 (3) a stock split does not occur in the years 2013-2014 (4) the results of the processing of statistical data meets classical assumption. Based on the criteria, the then banks selected are Bank Central Asia Tbk, Bank Negara Indonesia (Persero) Tbk, Bank Mandiri (Persero) Tbk, Bank Danamon Indonesia Tbk, Bank Rakyat Indonesia (Persero) Tbk, Bank Permata Tbk, Bank Pan Indonesia Tbk, Bank CIMB Niaga Tbk, Bank Negara Indonesia (Persero) Tbk and Bank International Indonesia Tbk. The dependent variable in this research is the stock price, while the dependent variable are Loan to Deposit Ratio (LDR), Non Performing Loans (NPL), Capital Adequacy Ratio (CAR) and Return on Equity (ROE). Data were analyzed using multiple linear regression analysis. The results showed that the independent variables (LDR, NPL, CAR, and ROE) simultaneously significant effect on the stock price. Partially, LDR, CAR and ROE have a significant effect on the stock price. Meanwhile, NPL has no effect on the stock price.
\end{abstract}

Keywords: Stock Price, LDR, NPL, CAR, ROE

\begin{abstract}
Abstrak: Penelitian ini bertujuan untuk mengetahui dampak rasio keuangan terhadap harga saham sepuluh bank terkemuka di Indonesia. Penelitian ini menggunakan metode purposive sampling untuk sepuluh bank yang go public di Bursa Efek Indonesia periode 2013-2014 dengan kriteria berikut : (1) memiliki aset dengan jumlah terbesar pada tahun 2013-2014 (2) memiliki informasi rasio keuangan pada tahun 2013-2014 (3) tidak terjadi pemecahan saham pada tahun 2013-2014 (4) hasil pengolahan data statistiknya memenuhi uji asumsi klasik. Berdasarkan kriteria itu, maka jumlah bank yang terpilih adalah Bank Central Asia Tbk, Bank Negara Indonesia (Persero) Tbk, Bank Mandiri (Persero) Tbk, Bank Danamon Indonesia Tbk, Bank Rakyat Indonesia (Persero) Tbk, Bank Permata Tbk, Bank Pan Indonesia Tbk, Bank CIMB Niaga Tbk, Bank Tabungan Negara (Persero) Tbk dan Bank International Indonesia Tbk. Variabel tidak bebas dalam penelitian ini adalah harga saham, sementara variabel terikat adalah Loan to Deposit Ratio (LDR), Non Performing Loans (NPL), Capital Adequacy Ratio (CAR) and Return on Equity (ROE). Data dianalisis dengan menggunakan analisa regresi linier berganda. Hasil penelitian menunjukkan bahwa variabel bebas (LDR, NPL, CAR, and ROE) secara simultan berpengaruh signifikan terhadap harga saham. Secara parsial, LDR, CAR dan ROE berpengaruh signifikan terhadap harga saham. Sementara, NPL tidak berpengaruh terhadap harga saham.
\end{abstract}

Kata kunci: Harga Saham, LDR, NPL, CAR, ROE 


\section{PENDAHULUAN}

Kinerja sepuluh perusahaan perbankan terkemuka di Indonesia menunjukkan perkembangan yang semakin meningkat pada tahun 2014. Pada tahun 2014, kesepuluh perusahaan tersebut mampu meraih laba komprehensif sebesar Rp 86.807 milyar. Angka ini meningkat bila dibandingkan dengan pencapaian laba sebesar $\mathrm{Rp} 71.133$ milyar pada tahun 2013.

Peningkatan laba ini diikuti dengan naiknya harga saham perusahaan tersebut. Hampir seluruh bank mengalami kenaikan harga saham pada tahun 2014, kecuali Bank CIMB Niaga dan Bank International Indonesia yang mengalami penurunan harga saham. Secara prosentase, Bank Pan Indonesia mengalami kenaikan harga saham tertinggi dengan peningkatan harga sebesar $77 \%$ dibandingkan dengan tahun 2013. Secara nominal, kenaikan harga saham tertinggi dibukukan oleh Bank Rakyat Indonesia dengan kenaikan harga sebesar Rp 4.500 per lembar saham dibandingkan dengan tahun 2013.

Naiknya harga saham disertai pula dengan kenaikan nilai kapitalisasi pasar saham pada periode tersebut. Pada tahun 2014, kesepuluh perbankan memeroleh nilai kapitalisasi pasar saham sebesar Rp 61.266 milyar. Sementara, pada tahun 2013 jumlah kapitalisasi pasar saham hanya Rp 48.178 milyar.

Tabel 1. Harga Saham, Nilai Kapitalisasi Saham dan Laba Komprehensif Bank

\begin{tabular}{|c|c|c|c|c|}
\hline Keterangan & Tahun & $\begin{array}{l}\text { Harga saham } \\
\text { penutupan } \\
\text { (rupiah) }\end{array}$ & $\begin{array}{c}\text { Nilai } \\
\text { kapitalisasi } \\
\text { pasar saham } \\
\text { (Milyar rupiah) }\end{array}$ & $\begin{array}{c}\text { Laba } \\
\text { komprehensif } \\
\text { (Milyar } \\
\text { rupiah) }\end{array}$ \\
\hline \multirow[t]{2}{*}{ Bank BCA } & 2014 & 13.125 & 14.446 & 16.925 \\
\hline & 2013 & 9.600 & 7.946 & 13.004 \\
\hline \multirow[t]{2}{*}{ Bank Mandiri } & 2014 & 10.775 & 14.584 & 21.483 \\
\hline & 2013 & 7.850 & 15.151 & 17.996 \\
\hline \multirow[t]{2}{*}{ Bank Rakyat Indonesia } & 2014 & 11.650 & 19.879 & 24.760 \\
\hline & 2013 & 7.250 & 15.265 & 19.917 \\
\hline \multirow[t]{2}{*}{ Bank Negara Indonesia } & 2014 & 6.100 & 9.163 & 11.915 \\
\hline & 2013 & 3.950 & 5.744 & 6.244 \\
\hline \multirow[t]{2}{*}{ Bank Danamon Indonesia } & 2014 & 4.525 & 897 & 2.818 \\
\hline & 2013 & 3.775 & 1.370 & 4.077 \\
\hline \multirow[t]{2}{*}{ Bank Tabungan Negara } & 2014 & 1.205 & 1.890 & 1.116 \\
\hline & 2013 & 870 & 702 & 1.443 \\
\hline \multirow[t]{2}{*}{ Bank CIMB Niaga } & 2014 & 835 & 81 & 2.695 \\
\hline & 2013 & 920 & 31 & 3.234 \\
\hline
\end{tabular}


Lanjutan Tabel 1

\begin{tabular}{lrrrr}
\hline Bank International Indonesia & 2014 & 208 & 11 & 753 \\
& 2013 & 310 & 1.773 & 1.245 \\
& & & & \\
Bank Permata & 2014 & 1.505 & 41 & 1.647 \\
& 2013 & 1.260 & 20 & 1.631 \\
Bank Pan Indonesia & & & & \\
& 2014 & 1.165 & 274 & 2.695 \\
& 2013 & 660 & 176 & 2.342 \\
Jumlah & & & & \\
& 2014 & & 61.266 & 86.807 \\
\hline
\end{tabular}

Sumber: publikasi statistik yearly \& laporan keuangan tahunan - www.idx.co.id

Beberapa penelitian tentang pengaruh kinerja keuangan terhadap harga saham telah dilakukan, namun dirasakan masih kurang memadai dari segi jumlahnya. Selain itu, hasil yang diperoleh dari penelitian itu beragam dan umumnya tidak konsisten. Beberapa hasil penelitian itu diantaranya adalah:

1. CAR tidak berpengaruh terhadap harga saham (Pryanka dkk, 2014; Yuneita Anisma, 2012; Andry Priharta \& Yolanda Irama, 2012 ; Indrijaya \& Stella. 2011; Wijayanti, 2010; Ratna Nurani, 2009; Fariyana Kusumawati, 2009). Sementara, hasil penelitian lainnya menunjukkan bahwa CAR berpengaruh terhadap harga saham (Sunyota \& Sam'ani, 2014; Nurjanti Takarini \& Ukki Hayudanto Putra 2013; Haryetti, 2012; Sendi Gusnandar Arnan \& Shinta Dewi Herawati 2011).

2. NPL tidak berpengaruh terhadap harga saham (Haryetti, 2012; Wijayanti, 2010; Fariyana Kusumawati, 2009).

3. LDR tidak berpengaruh terhadap harga saham (Pryanka dkk, 2014; Yuneita Anisma, 2012; Indrijaya \& Stella. 2011; Wijayanti, 2010; Ratna Nurani, 2009 ; Nurjanti Takarini \& Ukki Hayudanto Putra, 2013). Sebaliknya, hasil penelitian lain menunjukkan adanya pengaruh LDR terhadap harga saham (Haryetti, 2012 ; Andry Priharta dan Yolanda Irama, 2012 ; Sendi Gusnandar Arnan \& Shinta Dewi Herawati, 2011 ; Alvin Setiawan \& Lauw Tjun Tjun, 2010).

4. ROE berpengaruh terhadap harga saham (Pryanka dkk, 2014; Haryetti, 2012; Titiek Rachmawati \& Dwijono Kristijanto, 2009). Sedangkan Ratna Nurani (2009) berkesimpulan bahwa ROE tidak berpengaruh terhadap harga saham.

Tidak terdapatnya konsistensi dari hasil penelitian diatas, menarik perhatian penulis untuk melakukan penelitian tersendiri tentang pengaruh kinerja keuangan terhadap harga saham. Hanya saja, penelitian ini lebih difokuskan untuk menilai pengaruh kinerja keuangan terhadap harga saham bank terkemuka di Indonesia. Pertimbangan yang mendasarinya adalah bahwa bank-bank ini memiliki modal, kualitas aset, manajemen, rentabilitas, likuiditas dan sensitivitas terhadap risiko pasar yang relatif merata diantara mereka. Dengan demikian, kesimpulan yang diperoleh dapat mencerminkan tingkat pengaruh kinerja keuangan terhadap harga saham bank terkemuka saja. 


\section{KAJIAN TEORI}

Para investor pada umumnya menggunakan analisis fundamental atau analisis teknikal dalam menilai harga saham. Para analis fundamental merupakan tipe investor jangka panjang yang mengharapkan dividen daripada memeroleh keuntungan melalui aksi beli dan jual saham dalam jangka pendek. Menurut Bodie (2008), analis fundamental memperkirakan harga saham berdasarkan prospek laba dan dividen, ekspektasi tingkat bunga di masa mendatang dan risiko perusahaan. Analisis ini kemudian dilengkapi pula dengan telaah atas kondisi ekonomi yang lebih rinci, termasuk kualitas manajemen perusahaan, kekuatan perusahaan dalam industrinya dan prospek industri secara keseluruhan. Selaras dengan pendapat tersebut, Brown (2012) menyatakan bahwa analis fundamental memperkirakan harga saham berdasarkan pengamatan terhadap variabel ekonomi, industri dan perusahaan. Sebaliknya, para analis teknikal merupakan tipe investor jangka pendek yang mengharapkan keuntungan dari kenaikan harga saham melalui telaah data pasar masa lalu. Menurut Bodie (2008), analis teknikal mempelajari harga saham masa lalu untuk memprediksi harga saham di masa mendatang. Pergerakan harga saham di masa lalu diperkirakan akan membentuk suatu pola tertentu yang berulang di masa mendatang. Menemukan pola yang tepat merupakan dasar untuk membuat keputusan membeli dan menjual saham agar dapat meraih keuntungan. Hal yang sama juga dinyatakan oleh Brown. Menurut Brown (2012), para analis teknikal memperkirakan harga saham berdasarkan data pasar yang lalu seperti harga dan volume perdagangan.

Penelitian ini lebih memilih pendekatan fundamental guna mengetahui pengaruh kinerja keuangan terhadap harga saham perusahaan yang diteliti. Dasar pemikirannya, pendekatan fundamental mencerminkan pertimbangan yang objektif dalam menilai harga saham dibandingkan dengan pendekatan teknikal yang bersifat subjektif.

Secara lebih spesifik, beberapa ahli mengungkapkan pendapatnya mengenai faktor fundamental. Menurut Jaouida Elleuch (2009), faktor fundamental berkaitan dengan kinerja keuangan. Penilaian kinerja keuangan dapat dilakukan melalui analisis laporan keuangan perusahaan (Lukas Setia Atmaja, 2008 ; Van Horne dan Wachowicz, Jr 2008). Mehmet Sarac (2008) juga sependapat dengan menyatakan bahwa investor menggunakan analisis fundamental berupa analisis rasio dalam pengambilan keputusan investasinya.

\section{METODE}

Dalam penelitian ini, kinerja keuangan yang dijadikan tolak ukur dalam menentukan pengaruhnya terhadap harga saham terdiri dari rasio permodalan, rasio likuiditas, rasio profitabilitas dan kualitas aset. Kemudian, ditentukan masing-masing satu rasio keuangan yang untuk mewakili kelompok tersebut. Hasilnya, rasio-rasio yang dipilih untuk diteliti adalah LDR mewakili rasio likuiditas, NPL mewakili kualitas aset, CAR mewakili rasio permodalan dan ROE yang mewakili rasio profitabilitas.

Modal merupakan faktor yang sangat penting dalam rangka pengembangan usaha dan untuk menampung risiko kerugiannya. Kecukupan modal dalam usaha perbankan diukur melalui rasio CAR. Semakin tinggi rasio CAR, semakin tinggi tingkat kemampuan bank dalam menghadapi risiko kerugian dan semakin mampu melakukan pengembangan usaha untuk meningkatkan laba. Rasio loan to deposit ratio (LDR) berkaitan dengan likuiditas sebuah bank. Likuiditas menunjukkan ketersediaan dana agar bank setiap saat 
dapat memenuhi kewajiban-kewajiban yang harus dibayar dalam jangka pendek, selain juga harus mampu memenuhi semua permohonan kredit yang layak dibiayai.

Rasio non-performing loan (NPL) menunjukkan bahwa kemampuan bank dalam mengelola kredit bermasalah yang disalurkan oleh bank. Semakin tinggi rasio ini maka akan semakin besar kemungkinan suatu bank dalam kondisi bermasalah. Tingginya jumlah kredit bermasalah dalam suatu bank berakibat turunnya harga saham.

Rasio return on equity (ROE) sering digunakan untuk mengetahui tingkat pengembalian dari dana yang diinvestasikannya. Tingkat return on equity (ROE) yang semakin tinggi akan memengaruhi minat dari para investor terhadap saham bank sehingga mampu meningkatkan harga pasar saham.

Penelitian-penelitian terdahulu diantaranya memilih beberapa rasio keuangan dalam satu kelompok untuk diukur pengaruhnya terhadap harga saham. Misalnya, menurut penulis tidaklah tepat mengukur pengaruh rasio BOPO, NIM, ROA dan ROE secara bersamaan terhadap harga saham. Karena, rasio-rasio tersebut merupakan rasio profitabilitas yang sebagian besar terbentuk dari unsur-unsur yang sama dalam laporan keuangan. Akibatnya, diantara komponen tersebut saling tarik-menarik pengaruhnya terhadap harga saham.

Objek yang diteliti adalah kinerja keuangan dan harga saham bank pada periode 2013-2014. Faktor-faktor yang memengaruhi harga saham itu diuji melalui analisis regresi linier berganda dengan bantuan program SPSS versi 20. Untuk tujuan penelitian, data penelitian diperoleh melalui situs : www. idx.co.id.

Bank-bank yang dipilih untuk diteliti adalah 10 bank terkemuka dengan kriteria : memiliki aset dengan jumlah terbesar pada periode 2013-2014, memiliki informasi rasio keuangan pada periode 2013-2014, tidak melakukan pemecahan saham pada periode yang diteliti, dan hasil pengolahan data statistiknya memenuhi uji asumsi klasik. Berdasarkan kriteria itu, maka jumlah bank yang terpilih adalah Bank Central Asia Tbk, Bank Negara Indonesia (Persero) Tbk, Bank Mandiri (Persero) Tbk, Bank Danamon Indonesia Tbk, Bank Rakyat Indonesia (Persero) Tbk, Bank Permata Tbk, Bank Pan Indonesia Tbk, Bank CIMB Niaga Tbk, Bank Tabungan Negara (Persero) Tbk dan Bank International Indonesia Tbk.

\section{HASIL DAN PEMBAHASAN}

Rasio-rasio keuangan 10 bank terbesar di Indonesia menunjukkan kinerja yang beragam. Kinerja LDR beberapa bank mengalami penurunan seperti menurunnya LDR pada Bank Rakyat Indonesia, Bank Danamon, Bank Mandiri, dan Bank Permata. Kinerja NPL pada beberapa bank juga mengalami penurunan karena melaporkan adanya kenaikan rasio NPL, kecuali Bank Negara Indonesia, Bank Tabungan Negara, dan Bank Pan Indonesia yang melaporkan adanya penurunan NPL. Rasio CAR pada umumnya mengalami perbaikan, kecuali Bank Tabungan Negara dan Bank Permata yang mengalami penurunan CAR. Sementara, kinerja ROE secara umum mengalami penurunan, kecuali Bank Negara Indonesia yang melaporkan adanya kenaikan ROE sebesar 1,17\%. 
Tabel 2. Rasio Keuangan Bank

\begin{tabular}{|c|c|c|c|c|c|}
\hline KETERANGAN & TAHUN & LDR & NPL & CAR & ROE \\
\hline \multirow[t]{2}{*}{ Bank BCA } & 2014 & $76,80 \%$ & $0,6 \%$ & $16,90 \%$ & $25,50 \%$ \\
\hline & 2013 & $75,40 \%$ & $0,4 \%$ & $15,70 \%$ & $28,20 \%$ \\
\hline \multirow[t]{2}{*}{ Bank Mandiri } & 2014 & $82,02 \%$ & $1,66 \%$ & $16,60 \%$ & $25,81 \%$ \\
\hline & 2013 & $82,97 \%$ & $1,60 \%$ & $14,93 \%$ & $27,31 \%$ \\
\hline \multirow[t]{2}{*}{ Bank Rakyat Indonesia } & 2014 & $81,86 \%$ & $1,69 \%$ & $18,31 \%$ & $31,22 \%$ \\
\hline & 2013 & $88,54 \%$ & $1,55 \%$ & $16,99 \%$ & $34,11 \%$ \\
\hline \multirow[t]{2}{*}{ Bank Negara Indonesia } & 2014 & $87,81 \%$ & $1,96 \%$ & $16,22 \%$ & $23,64 \%$ \\
\hline & 2013 & $85,30 \%$ & $2,17 \%$ & $15,09 \%$ & $22,47 \%$ \\
\hline \multirow[t]{2}{*}{ Bank Danamon Indonesia } & 2014 & $92,60 \%$ & $2,3 \%$ & $17,90 \%$ & $8,60 \%$ \\
\hline & 2013 & $95,10 \%$ & $1,9 \%$ & $17,90 \%$ & $14,52 \%$ \\
\hline \multirow[t]{2}{*}{ Bank Tabungan Negara } & 2014 & $108,60 \%$ & $4,01 \%$ & $14,64 \%$ & $10,66 \%$ \\
\hline & 2013 & $104,42 \%$ & $4,05 \%$ & $15,62 \%$ & $16,05 \%$ \\
\hline \multirow[t]{2}{*}{ Bank CIMB Niaga } & 2014 & $99,46 \%$ & $3,90 \%$ & $15,58 \%$ & $8,52 \%$ \\
\hline & 2013 & $94,49 \%$ & $2,23 \%$ & $15,36 \%$ & $17,74 \%$ \\
\hline \multirow[t]{2}{*}{ Bank International Indonesia } & 2014 & $92,67 \%$ & $2,23 \%$ & $15,72 \%$ & $6,02 \%$ \\
\hline & 2013 & $87,04 \%$ & $2,11 \%$ & $12,72 \%$ & $16,18 \%$ \\
\hline \multirow[t]{2}{*}{ Bank Permata } & 2014 & $89,13 \%$ & $1,70 \%$ & $13,58 \%$ & $12,17 \%$ \\
\hline & 2013 & $89,24 \%$ & $1,02 \%$ & $14,28 \%$ & $15,68 \%$ \\
\hline \multirow[t]{2}{*}{ Bank Pan Indonesia } & 2014 & $90,51 \%$ & $2,05 \%$ & $15,62 \%$ & $13,09 \%$ \\
\hline & 2013 & $87,71 \%$ & $2,13 \%$ & $15,32 \%$ & $14,56 \%$ \\
\hline
\end{tabular}

Sumber: laporan keuangan tahunan - www.idx.co.id

Pengujian Asumsi Klasik. Penelitian ini menggunakan analisis linier berganda untuk menguji pengaruh antara LDR, NPL, CAR dan ROE terhadap Harga Saham. Uji asumsi klasik merupakan prasyarat yang harus dilakukan terlebih dahulu untuk mengetahui kelayakan suatu model regresi berganda. Uji normalitas, uji multikolinieritas, uji heteroskedastisitas, dan uji autokorelasi merupakan bagian dari uji asumsi klasik.

Uji Normalitas. Uji normalitas dilakukan bertujuan untuk melihat apakah data memunyai distribusi atau penyebaran secara normal atau tidak di dalam model regresi. Model regresi yang baik memiliki data yang terdistribusi secara normal. Salah satu cara untuk melihat 
data yang digunakan dalam penelitian terdistribusi secara normal atau tidak adalah melalui uji Kolmogorov-Smirnov (K-S). Hasil pengujian normalitas dapat dilihat melalui Tabel 3.

Tabel 3. Uji Normalitas

\begin{tabular}{llr}
\hline \multicolumn{2}{c}{ One-Sample Kolmogorov-Smirnov Test } \\
\hline $\mathrm{N}$ & & Unstandardized Residual \\
Normal Parameters ${ }^{\mathrm{a}, \mathrm{b}}$ & Mean & 20 \\
& Std. Deviation & $0 \mathrm{E}-7$ \\
Most Extreme & Absolute & 1385,77493960 \\
Differences & Positive &, 133 \\
Kolmogorov-Smirnov Z & Negative &,- 096 \\
Asymp. Sig. (2-tailed) &, 597 \\
\hline \multicolumn{2}{l}{ a. Test distribution is Normal. } \\
b. Calculated from data. &, 868 \\
\hline
\end{tabular}

Dari hasil uji normalitas diketahui bahwa nilai signifikansi (Asymp.Sig 2 - tailed) sebesar 0,868. Karena signifikansi lebih dari 0,05 $(0,868>0,05)$ maka nilai residual terdistribusi secara normal atau memenuhi asumsi klasik normalitas.

Uji Multikolinearitas. Uji multikolinearitas bertujuan untuk menguji apakah model regresi ditemukan adanya korelasi antar variabel bebas. Model regresi yang baik adalah tidak terjadi multikolinearitas sempurna. Untuk mengetahui terjadinya multikolinearitas dapat melalui Tolerance dan Variance Inflation Factor (VIF). Kedua ukuran ini menunjukkan setiap variabel bebas manakah yang dijelaskan oleh variabel bebas lainnya. Hasil yang ditunjukan dalam output SPSS maka besarnya tolerance dan VIF dari keempat variabel bebas yang digunakan (LDR, NPL, CAR dan ROE) dapat dilihat melalui Tabel 4.

Tabel 4. Uji Multikolinearitas

\begin{tabular}{|c|c|c|c|c|c|c|c|c|}
\hline \multirow{3}{*}{\multicolumn{2}{|c|}{ Model }} & \multicolumn{5}{|c|}{ Coefficients $^{\mathrm{a}}$} & \multirow{2}{*}{\multicolumn{2}{|c|}{$\begin{array}{l}\text { Collinearity } \\
\text { Statistics }\end{array}$}} \\
\hline & & \multicolumn{2}{|c|}{$\begin{array}{l}\text { Unstandardized } \\
\text { Coefficients }\end{array}$} & \multirow{2}{*}{$\begin{array}{c}\text { Standardized } \\
\text { Coefficients } \\
\text { Beta }\end{array}$} & \multirow[t]{2}{*}{$\mathrm{t}$} & \multirow[t]{2}{*}{ Sig. } & & \\
\hline & & B & Std. Error & & & & Tolerance & VIF \\
\hline \multirow{5}{*}{1} & (Constant) & 5606,854 & 9950,352 & &, 563 &, 581 & & \\
\hline & $\mathrm{ldr}$ & $-304,468$ & 108,444 &,- 594 & $-2,808$ & ,013 & ,181 & 5,513 \\
\hline & $\mathrm{npl}$ & 966,051 & 774,936 & 220 & 1,247 & ,232 & ,262 & 3,823 \\
\hline & car & 1262,192 & 288,419 & ,411 & 4,376 & ,001 & ,920 & 1,087 \\
\hline & roe & 214,755 & 69,059 & ,405 & 3,110 & ,007 & ,480 & 2,085 \\
\hline
\end{tabular}

a. Dependent Variable: harga_saham

Nilai tolerance masing-masing variabel lebih dari 0,1 dan nilai VIF masing-masing variabel kurang dari 10 maka dapat disimpulkan bahwa tidak terjadi masalah multikolinearitas pada model regresi.

Uji autokorelasi. Uji autokorelasi bertujuan untuk menguji apakah dalam model regresi berganda terdapat korelasi antar kesalahan pengganggu (residual) pada periode $t$ dengan kesalahan pada periode sebelumnya t-1. Model regresi yang baik adalah regresi yang 
bebas dari autokorelasi. Kesimpulan untuk menentukan terjadinya autokorelasi ataupun tidak, dilakukan melalui uji Durbin-Watson (DW).

Tabel 5. Uji Autokorelasi

\begin{tabular}{lrrrrr} 
Model & R & R Square & $\begin{array}{c}\text { Model Summary } \\
\text { Adjusted R } \\
\text { Square }\end{array}$ & $\begin{array}{l}\text { Std. Error of } \\
\text { the Estimate }\end{array}$ & $\begin{array}{l}\text { Durbin- } \\
\text { Watson }\end{array}$ \\
\hline 1 & $\quad 937^{\mathrm{a}}$ &, 878 &, 846 & 1672,18452 & 1,175 \\
\hline
\end{tabular}

a. Predictors: (Constant), roe, car, npl, ldr

b. Dependent Variable: harga_saham

Hasil dari uji Durbin-Watson (DW) menunjukkan nilai sebesar 1,175. Nilai dU dan dL dapat diperoleh dari tabel statistik Durbin Watson. Dengan menggunakan tingkat signifikansi sebesar 0,05 pada $\mathrm{n}=20$ dan $\mathrm{k}=4$, diperoleh batas luar (dL) sebesar 0,894 dan batas dalam (dU) sebesar 1,828. Karena hasil pengujian menunjukkan bahwa dL < $\mathrm{DW}<\mathrm{dU}(0,894<1,175<1,828)$, dapat dikatakan bahwa tidak ada kepastian atau kesimpulan yang pasti.

Uji Heteroskedastisitas. Pengujian heteroskedastisitas dilakukan untuk mengetahui apakah dalam model regresi terjadi ketidaksamaan varian dari residual pada satu pengamatan ke pengamatan yang lainnya. Model regresi yang baik adalah tidak terjadi heteroskedastisitas. Model regresi yang baik adalah terjadi homoskedastisitas yang berarti sama (homo) dan sebaran (scedasticity) memiliki variance yang sama (equal variance) (Ghozali, 2011). Untuk menentukan hasil dari heteroskedastisitas dapat menggunakan pengujian statistik yaitu uji Glejser. Hasil uji Glejser dapat dilihat pada Tabel 6.

Tabel 6. Uji Heteroskedastisitas

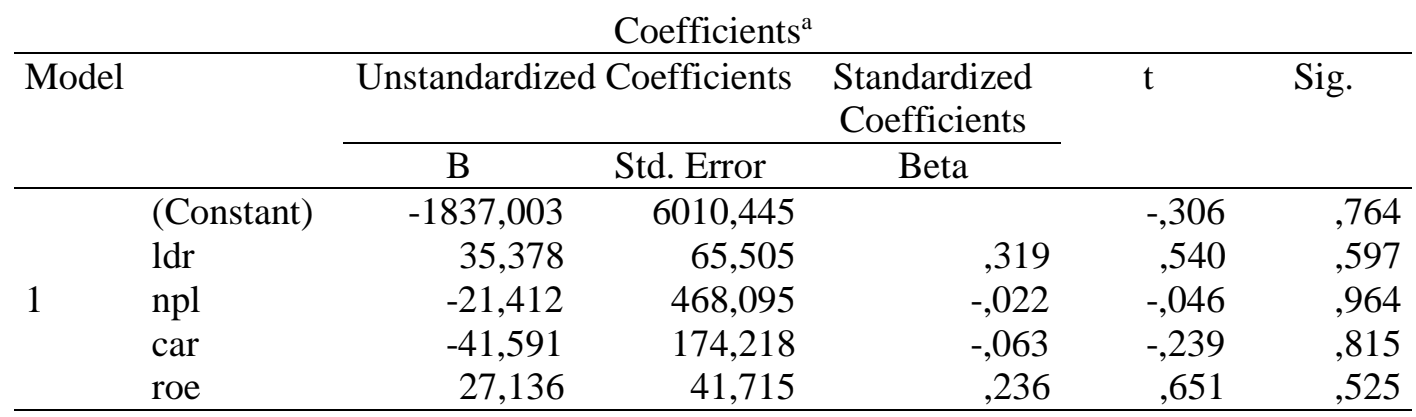

a. Dependent Variable: ABS_RES

Dari Tabel 6 dapat diketahui bahwa nilai signifikansi masing-masing dari keempat variabel independen lebih dari 0,05 . Dengan demikian dapat disimpulkan bahwa tidak terjadi masalah heteroskedastisitas pada model regresi.

Pengujian Regresi Linier Berganda. Analisis statistik yang digunakan dalam penelitian ini yaitu regresi linier berganda. Analisis ini digunakan untuk mengetahui besarnya pengaruh variabel-variabel bebas (independen) yaitu LDR, NPL, CAR dan ROE terhadap variabel terikat (dependen) yaitu Harga Saham. Berdasarkan perhitungan melalui komputer dengan menggunakan program SPSS versi 20 diperoleh hasil regresi sebagaimana terlihat pada Tabel 7. 
Tabel 7. Uji Regresi Linier Berganda

\begin{tabular}{|c|c|c|c|c|c|c|}
\hline & & & Coefficients & & & \\
\hline & & Unstandardized & Coefficients & Standardized & $\mathrm{t}$ & Sig. \\
\hline & & B & Std. Error & Beta & & \\
\hline & (Constant) & 5606,854 & 9950,352 & & ,563 & ,581 \\
\hline & ldr & $-304,468$ & 108,444 &,- 594 & $-2,808$ & ,013 \\
\hline 1 & $\mathrm{npl}$ & 966,051 & 774,936 & ,220 & 1,247 & ,232 \\
\hline & car & 1262,192 & 288,419 & ,411 & 4,376 & ,001 \\
\hline & roe & 214,755 & 69,059 & ,405 & 3,110 & ,007 \\
\hline
\end{tabular}

a. Dependent Variable: harga_saham

Berdasarkan hasil pengujian regresi linier diatas, pengaruh variabel-variabel bebas terhadap harga saham dapat ditentukan dengan persamaan berikut:

Harga Saham $=5.606,85+1.262,19 \mathrm{CAR}+966,05 \mathrm{NPL}+214,75 \mathrm{ROE}-304,47 \mathrm{LDR}$ Dari persamaan tersebut diketahui bahwa variabel bebas yang paling besar pengaruhnya adalah CAR dengan koefisien sebesar 1.262,192. Variabel yang paling kecil pengaruhnya adalah ROE dengan koefisien 214,755. Dari persamaan tersebut dapat terlihat juga bahwa variabel bebas CAR dan ROE berpengaruh positif terhadap Harga Saham yang berarti meningkatnya kedua variabel ini akan menaikkan nilai Harga Saham. Sedangkan variabel LDR memberikan pengaruh negatif terhadap Harga Saham, yang berarti meningkatnya LDR mengakibatkan menurunnya nilai Harga Saham.

Uji Koefisien Determinasi. Koefisien determinasi $R$ square $\left(\mathrm{R}^{2}\right)$ pada intinya mengukur seberapa jauh kemampuan variabel independen mempengaruhi dependen. Hasil pengujian koefisien determinasi dapat dilihat pada Tabel 8.

Tabel 8. Uji Koefisien Determinasi

\begin{tabular}{lcccc}
\multicolumn{5}{c}{ Model Summary } \\
\hline Model & R & R Square & $\begin{array}{c}\text { Adjusted R } \\
\text { Square }\end{array}$ & $\begin{array}{c}\text { Std. Error of the } \\
\text { Estimate }\end{array}$ \\
\hline 1 &, $937^{\text {a }}$ &, 878 &, 846 & 1672,18452 \\
\hline a. Predictors: (Constant), roe, car, npl, ldr & &
\end{tabular}

Berdasarkan Tabel di atas, koefisien determinasi $\mathrm{R}$ square $\left(\mathrm{R}^{2}\right)$ adalah sebesar 0,878 . Hal ini berarti 87,8\% Harga Saham dipengaruhi oleh variabel LDR, NPL, CAR dan ROE, sisanya dipengaruhi variabel lain yang tidak termasuk dalam pengujian ini.

Hipotesis - Hipotetis. Hipotesis berfungsi sebagai pegangan sementara atau jawaban sementara yang masih harus dibuktikan kebenarannya di dalam kenyataan (empirical verification), percobaan (experimentation) atau praktik (implementation). Dalam hipotesis diperlukan adanya asumsi dasar yang dimuat secara bebas tetapi logis, asumsi tersebut menjelaskan bahwa hipotesis merupakan jawaban sementara terhadap permasalahan penelitian sampai terbukti atau tidaknya hasil penelitian. Hipotesis dalam penelitian ini adalah:

Ho : LDR, NPL, CAR dan ROE secara simultan tidak berpengaruh terhadap harga saham.

H1 : LDR secara parsial tidak berpengaruh terhadap harga saham.

H2 : NPL secara parsial tidak berpengaruh terhadap harga saham. 
H3 : CAR secara parsial tidak berpengaruh terhadap harga saham.

H4 : ROE secara parsial tidak berpengaruh terhadap harga saham.

Uji Statistik F. Uji F atau uji statistik F pada dasarnya menunjukkan apakah semua variabel bebas yang digunakan dan dimasukkan ke dalam model mempunyai pengaruh secara bersama-sama atau simultan terhadap variabel terikat. Dalam hal ini untuk mengetahui apakah variabel LDR, NPL, CAR dan ROE berpengaruh atau tidak berpengaruh terhadap Harga Saham. Hasil uji statistik F ditunjukkan pada Tabel 9.

Tabel 9. Uji Statistik F

\begin{tabular}{|c|c|c|c|c|c|c|}
\hline \multicolumn{7}{|c|}{$\mathrm{ANOVA}^{\mathrm{a}}$} \\
\hline Model & & Sum of Squares & $\mathrm{df}$ & Mean Square & $\mathrm{F}$ & Sig. \\
\hline \multirow{3}{*}{1} & Regression & 302421775,548 & 4 & 75605443,887 & 27,039 &, $000^{\mathrm{b}}$ \\
\hline & Residual & 41943016,252 & 15 & 2796201,083 & & \\
\hline & Total & 344364791,800 & 19 & & & \\
\hline
\end{tabular}

a. Dependent Variable: harga_saham

b. Predictors: (Constant), roe, car, npl, ldr

Berdasarkan hasil tabel uji ANOVA atau $F$ test yang ditunjukkan pada Tabel 9 diperoleh nilai $\mathrm{F}$ hitung sebesar 27,039 dengan tingkat signifikansi 0,000. F tabel statistik pada tingkat signifikansi 0,05 dengan df $1=4$ dan df $2=15$, diperoleh hasil untuk $\mathrm{F}$ tabel sebesar 3,056. Karena F hitung > F tabel atau 27,039 > 3,056 maka Ho ditolak. Jadi dapat disimpulkan bahwa keempat variabel bebas secara simultan berpengaruh terhadap Harga Saham. Dengan tingkat signifikasi dibawah 0,05 $(0,002<0,05)$ maka disimpulkan bahwa keempat variabel bebas berpengaruh signifikan terhadap variabel terikat.

Uji Statistik t. Uji t atau uji statistik t pada dasarnya menunjukkan seberapa jauh pengaruh satu variabel bebas terhadap variabel terikat dengan menganggap variabel bebas lainnya konstan (Ghozali, 2011:17). Dalam hal ini untuk mengetahui apakah secara parsial variabel LDR, NPL, CAR dan ROE berpengaruh atau tidak berpengaruh terhadap Harga Saham. Hasil uji statistik t dapat ditunjukkan pada Tabel 10.

Tabel 10. Uji Statistik t

\begin{tabular}{rlrrrrr}
\hline Model & & Unstandardized Coefficients & \multicolumn{2}{c}{$\begin{array}{c}\text { Standardized } \\
\text { Coefficients }\end{array}$} & \multicolumn{1}{c}{$\mathrm{t}$} & \multirow{2}{*}{ Sig. } \\
\cline { 3 - 5 } & & \multicolumn{1}{c}{$\mathrm{B}$} & \multicolumn{1}{c}{ Std. Error } & \multicolumn{1}{c}{ Beta } & & \\
\hline & (Constant) & 5606,854 & 9950,352 & &, 563 &, 581 \\
& ldr & $-304,468$ & 108,444 &,- 594 & $-2,808$ &, 013 \\
1 & npl & 966,051 & 774,936 &, 220 & 1,247 &, 232 \\
& car & 1262,192 & 288,419 &, 411 & 4,376 &, 001 \\
& roe & 214,755 & 69,059 &, 405 & 3,110 &, 007 \\
\hline
\end{tabular}

a. Dependent Variable: harga_saham

Nilai t tabel dengan tingkat signifikansi $0,05 / 2=0,025$ (uji 2 sisi), pada derajat kebebasan df $=15$, diperoleh nilai t tabel sebesar $-2,086 / 2,086$. Dengan membandingkan antara thitung dan $t$ tabel maka diperoleh hasil sebagai berikut:

1. Karena t hitung LDR > t tabel LDR $(2,808>2,086)$ maka H1 ditolak, artinya LDR berpengaruh terhadap harga saham 
2. Karena t hitung NPL $<$ t tabel NPL $(1,247<2,808)$ maka H2 diterima, artinya NPL tidak berpengaruh terhadap harga saham.

3. Karena t hitung CAR > t tabel CAR $(4,376>2,808)$ maka H3 ditolak, artinya CAR berpengaruh terhadap harga saham.

4. Karena t hitung ROE > t tabel $\operatorname{ROE}(3,110>2,808)$ maka H4 ditolak, artinya ROE berpengaruh terhadap harga saham.

Berdasarkan hasil pengujian tersebut juga diketahui bahwa tingkat signifikansi LDR, CAR, ROE masing-masing sebesar 0,013, 0,001 dan 0,007. Karena tingkat signifikansi tersebut berada dibawah 0,05 maka dapat dikatakan LDR, CAR, ROE secara parsial berpengaruh signifikan terhadap harga saham. Sementara tingkat signifikansi NPL sebesar 0,232 atau berada diatas 0,05 . Dengan demikian dapat dikatakan NPL tidak signifikan terhadap harga saham.

Secara rata-rata, rasio LDR 10 bank mengalami kenaikan kinerja dari 89,02\% pada tahun 2013 menjadi 90,17\% pada tahun 2014. Sejalan dengan rasio LDR, kinerja rasio CAR juga mengalami perbaikan dari rata-rata sebesar 15,39\% pada tahun 2013 menjadi rata-rata sebesar $16,11 \%$ pada tahun 2014. Namun, kinerja rasio NPL dan rasio ROE mengalami penurunan. Rasio NPL naik dari rata-rata sebesar 1,92\% pada tahun 2013 menjadi rata-rata sebesar $2,21 \%$ pada tahun 2014 . Rasio ROE turun dari rata-rata sebesar 20,68\% pada tahun 2013 menjadi rata-rata sebesar 16,52\% pada tahun 2014 .

Walaupun terjadi penurunan kinerja pada rasio NPL dan ROE, namun rata-rata harga saham 10 bank menunjukkan kenaikan dari rata-rata sebesar Rp. 3.644,50 per lembar saham pada tahun 2013 menjadi rata-rata sebesar Rp. 5.109,30 per lembar saham pada tahun 2014. Kenaikan harga saham ini dapat terjadi karena harga saham sangat dipengaruhi oleh kenaikan rasio CAR yang terjadi pada tahun 2014. Sebagaimana yang dihasilkan dari rumusan regresi linier diatas ; Harga Saham $=5.606,85+1.262,19 \mathrm{CAR}+$ 966,05 NPL + 214,75ROE - 304,47LDR

\section{PENUTUP}

Simpulan. Berdasarkan hasil penelitian yang telah dilakukan dalam menguji pengaruh variabel LDR, NPL, CAR dan ROE terhadap harga saham bank terkemuka di Indonesia pada periode 2013-2014, diperoleh kesimpulan bahwa secara parsial LDR, CAR, ROE berpengaruh signifikan terhadap harga saham. Sementara NPL tidak berpengaruh terhadap harga saham. Secara simultan LDR, NPL, CAR dan ROE berpengaruh signifikan terhadap harga pasar saham. Dengan koefisien determinasi $\mathrm{R}$ square $\left(\mathrm{R}^{2}\right)$ sebesar 0,878 , berarti perubahan LDR, NPL, CAR dan ROE secara bersama-sama dapat digunakan sebagai variabel untuk memprediksi perubahan harga saham.

Saran. Bagi para peneliti selanjutnya, disarankan untuk mengukur pengaruh kinerja keuangan terhadap harga saham dengan membandingkan langsung pos-pos tertentu dalam laporan keuangan terhadap harga saham tersebut. Misalnya, mengukur pengaruh laba bersih terhadap harga saham, mengukur pengaruh arus kas dari aktivitas operasi terhadap harga saham dan seterusnya. Sehingga dapat meminimalisir kesimpulan yang mungkin menjadi bias akibat adanya perbedaan kebijakan dalam mengukur rasio keuangan yang sama pada masing-masing bank. 


\section{DAFTAR RUJUKAN}

Anisma, Yuneita. (2012) "Faktor-Faktor Yang Mempengaruhi Harga Saham Perusahaan Perbankan Yang Listing di Bursa Efek Indonesia". Jurnal Sosial Ekonomi Pembangunan, Tahun II (5). Maret 2012. Hal.144-165

Atmaja, Lukas Setia. (2008) Manajemen Keuangan. Yogyakarta : Penerbit Andi

Bodie, Zvi. Kane, Alex. dan Markus, Alan J (2008) Essentials of Investments. Seventh Edition. New York : McGraw-Hill.

Reilly, Frank. dan Brown, Keith (2012) Investment Analysis and Portofolio Management. Tenth Edition. Mason - Ohio: South - Western Cengage Learning.

Elleuch, Jaouida. (2009) "Fundamental Analysis Strategy and the Prediction of Stock Returns". International Research Journal of Finance and Economics. August 30, 2009. Page 95-108

Ghozali, Imam. (2011) Aplikasi Analisis Multivariate Dengan Program IBM SPSS 19. Semarang: Universitas Diponegoro

Gusnandar Arnan, Sendi dan Dewi Herawati, Shinta. (2011) "Pengaruh Kinerja Keuangan Terhadap Harga Saham Subsektor Perbankan di Bursa Efek Indonesia”. Jurnal Bisnis dan Manajemen Vol.7 (2). Januari 2011. Hal 123-153

Haryetti. (2012) "Analisis Pengaruh Kinerja Keuangan Terhadap Harga Saham Pada Perusahaan Perbankan yang Go Public di Bursa Efek Indonesia". Jurnal Sosial Ekonomi Pembangunan, Tahun III (7). November 2012. Hal 88 - 102.

Indrijaya, Stella. (2011) "Analisis Pengaruh Rasio Camel Terhadap Harga Saham Bank Yang Listing di Bursa Efek Indonesia Periode 2006 - 2009”. Jurnal Ekonomi dan Bisnis, Fakultas Ekonomi Universitas Katolik Indonesia Atma Jaya. Vol.2 (1). Desember 2011. Hal 39-59.

Kusumawati, Fariyana. (2009) "Pengaruh Risiko Bank dan Profitabilitas Terhadap Harga Pasar Saham Perusahaan Perbankan". Jurnal Akuntansi, Manajemen Bisnis dan Sektor Publik. Vol. 6 (1). Oktober 2009. Hal. 18-41.

Nurani, Ratna. (2009) "Pengaruh Faktor-Faktor Fundamental Terhadap Harga Saham Pada Industri Perbankan di Bursa Efek Jakarta". Jurnal Tepak Manajemen Bisnis.Vol.1 (2) Hal. 63-81

Polii, Pryanka J.V. Saerang, Ivonne. dan Mandagie, Yunita. (2014) "Rasio Keuangan Pengaruhnya Terhadap Harga Saham Pada Bank Umum Swasta Nasional Devisa Yang Go Public di Bursa Efek Indonesia”. Jurnal EMBA, 993 Vol.2 (2). Juni 2014. Hal 993-1004.

Priharta, Andry dan Irama, Yolanda. (2012) "Analisis Pengaruh Kinerja Keuangan Terhadap Harga Pasar Saham (Studi Kasus Saham Perbankan BUMN di BEI)". Jurnal Iqtishad, Vol. 12 (27). Desember 2012. Hal 1-22

Rachmawati, Titiek dan Kristijanto, Dwijono. (2009) "Pengaruh Return on Aset (ROA), Return on Equity (ROE), Net Interest Marjin (NIM), dan Rasio Biaya Operasional Pendapatan Operasional (BOPO) Terhadap Harga Saham Bank di Bursa Efek Indonesia”. Jurnal Ilmu Ekonomi dan Manajemen, Volume 6 (1). Oktober 2009. Hal. 67-94

Setiawan, Alvin dan Tjun Tjun, Lauw (2010) "Pengaruh Earning Per Share, Loan to Deposit Ratio dan Arus Kas Operasi Terhadap Harga Saham Emiten Sektor Perbankan di Brusa Efek Indonesia”. Jurnal Akuntansi, Vol. 2 (2). Hal 162-180. 
Sunyota dan Sam'ani. (2014) "Pengaruh Capital Adequacy Ratio, Net Interest Margin dan Return on Asset Terhadap Harga Saham Pada Perbankan di BEI Periode 2009 2012”. Jurnal Ekonomi Manajemen dan Akuntansi. Th. XXI (36). Hal 1-19.

Takarini, Nurjanti dan Hayudanto Putra, Ukki. (2013) "Dampak Tingkat Kesehatan Bank Terhadap Perubahan Harga Saham Pada Perusahaan Perbankan Yang Go Public di Bursa Efek Indonesia”. Jurnal NeO-Bis. Vol 7 (2). Desember 2013. Hal 80-91.

Van Horne, James C dan Wachowicz, John M.Jr. (2008) Fundamentals of Financial Management. Thirteenth Edition. England : Prentice Hall.

Wijayanti. (2010) "Analisis Kinerja Keuangan dan Harga Saham Perbankan di Bursa Efek Indonesia'. Journal of Indonesian Applied Economics Vol. 4 (1). Mei 2010. Hal 7180 